\title{
Intervention to prevent intestinal parasitic reinfections among Tarahumara indigenous schoolchildren in northern Mexico
}

\author{
Joel Monárrez-Espino, ${ }^{1}$ Cristina Rocío Pérez-Espejo, ${ }^{1}$ \\ Guillermo Vázquez-Mendoza, ${ }^{2}$ Andrés Balleza-Carreón, ${ }^{3}$ \\ and Ramiro Caballero-Hoyos ${ }^{4}$
}

Suggested citation

Monárrez-Espino J, Pérez-Espejo CR, Vázquez-Mendoza G, Balleza-Carreón A, Caballero-Hoyos R. Intervention to prevent intestinal parasitic reinfections among Tarahumara indigenous schoolchildren in northern Mexico. Rev Panam Salud Publica. 2011;30(3):196-203.

ABSTRACT Objective. To assess the effectiveness of a 20-week, broad intervention to prevent reinfection by Ascaris lumbricoides $(A L)$ and Giardia lamblia $(G L)$ among indigenous schoolchildren in northern Mexico.

Methods. A prospective, comparative, ecological study. Two isolated boarding schools, each hosting 100-120 children, 4-15 years of age, were selected based on physical infrastructure: intervention school (IS), modern; control school (CS), deprived. After initial diagnosis, children with positive stool samples received supervised treatment with oral nitazoxanide. Diagnoses were made with at least one positive microscopic result from two serial samples using the Faust technique, as reported by the independent observations of two trained, laboratory technicians. Post-treatment samples were taken, and only those with negative results were followed-up. The intervention included infrastructure improvements/maintenance and an educational preventive program for children, parents, and school personnel; no activities were undertaken in the CS.

Results. Baseline prevalence for AL was $37.5 \%$ at the IS versus $16.6 \%$ at the CS $(\mathrm{P}<0.01)$; and for GL, $51.7 \%$ versus $37.8 \%$, respectively. At the IS, $35.7 \%$ did not speak Spanish, compared to $6.7 \%$ in the CS $(\mathrm{P}<0.01)$. Cure rates were similar in both schools for $A L(\sim 98 \%)$ and GL $(\sim 80 \%)$. Final prevalence and reinfection rates for GL were $10.4 \%$ versus $10.8 \%$, and $17.2 \%$ versus $21 \%$ at the IS and CS, respectively. No children were infected/reinfected with AL in either school. Follow-up rates were $80 \%-83 \%$ at the CS and 90\%-95\% at the IS.

Conclusions. Infection/reinfection rates were similar at the schools after 20 weeks. Supervised treatment alone every semester could effectively control AL/GL infections in this indigenous setting.

Key words Parasitic diseases, ascariasis; giardiasis; indigenous population; indigenous health; intervention studies; school sanitation; Mexico.

Unidad de Investigación en Epidemiología Clínica, Instituto Mexicano del Seguro Social, Chihuahua, Mexico. Send correspondence to Joel MonárrezEspino, email: jmonarrez@hotmail.com

2 Comisión Nacional para el Desarollo de los Pueblos Indígenas de México, Centro Coordinador de Guachochi, Chihuahua, Mexico.

Hospital Rural Oportunidades No. 26, Instituto Mexicano del Seguro Social, Guachochi, Chihuahua, Mexico.
Intestinal parasites spend part of their lifecycle in the human's digestive tract where they multiply and adapt expressing their pathogenicity (1). Infections are endemic in poor and marginalized

4 Unidad de Investigación en Epidemiología Clínica, Instituto Mexicano del Seguro Social, Colima, Mexico. tropical and subtropical geographic areas, those often inhabited by indigenous groups. Intestinal parasites constitute a relevant public health concern among children from rural Mexico where environmental, socioeconomic, and demographic risk factors increase transmission (2-4). 
Parasite infections relate to poor sanitation, inadequate personal hygiene, and ingestion of contaminated foods and water (5-8). Although in the latent phase, most parasites can be tolerated asymptomatically (9), active infections, especially by multiple parasites (10-11), can cause health problems and developmental deficits in schoolchildren $(3,9$, 12-14). Reinfection is one of the main concerns in endemic areas with precarious socioeconomic conditions; in these poor settings, a large proportion of persons can be reinfected in a relatively short period of time (15-17).

At the school level, the World Health Organization (WHO) has recommended three main control strategies to prevent intestinal parasitic infections: (a) periodic deworming treatment; (b) improved sanitation and safe water supply; and (c) health education (18). However, there is very limited evidence of the combined effect of these interventions on reinfection rates for helminths and protozoa among indigenous schoolchildren, particularly those in remote areas.

Of the three WHO-recommended strategies, the health educational component has been the primary focus, and various programs have been devised to promote healthy behaviors (5). Recently, in some countries, health promotion and awareness campaigns have used influential individuals or "peer leaders" to persuade others to adopt new practices $(19,20)$, but this strategy has yet to be applied to prevention and control of intestinal parasitic diseases. Peer leaders within a community can be identified through centrality measures similar to those used in social network analyses $(21,22)$.

Taking all this into account, the present study was aimed at assessing the effectiveness of a 20-week, broad intervention among indigenous Tarahumara schoolchildren using peer leaders to promote hygienic practices to prevent infection and reinfection by two of the area's most prevalent intestinal parasites, Ascaris lumbricoides (AL), a helminth; and Giardia lamblia (GL), a protozoa. Prevalence of these parasites in this area had been previously identified by an earlier study (23).

\section{METHODS}

\section{Study design}

This was a school-based, prospective, comparative, ecological trial. Figure 1 il- lustrates the study flow, beginning with the total number of registered children at the intervention school (IS) and at the control school (CS), through the final sample followed for 20 weeks.

After initial stool sampling, children with a positive diagnosis for either parasite received supervised treatment. Posttreatment samples were then taken, and only those with negative results were followed-up. The intervention included infrastructure improvements/maintenance and an educational, preventive program for children, parents, and school personnel. Although no activities apart from the initial antiparasite treatment were undertaken at the CS, a plan was in place to introduce similar measures if the intervention proved successful at the IS.

The proposal was reviewed and approved by the National Council for Science and Technology (Project FOMIX: Grant No. 23223; Fondo Mixto del Consejo Nacional de Ciencia y Tecnología y el Gobierno del Estado de Chihuahua); by the Health Research Committee and the Ethics Committee of the Mexican Institute of Social Security (Comisión Nacional de Investigación Científica y Comisión de Ética para la Investigación en Salud del Instituto Mexicano del Seguro Social, Mexico City); and by the National Commission for the Development of Indigenous Peoples (CDI; Comisión Nacional para el Desarrollo de los Pueblos Indígenas, Chihuahua). Witnessed, verbal, informed consent was obtained from all participating children and their parents.

\section{Study population}

The Tarahumara or Rarámuri, as they are known in their own language, is the largest ethnic minority in northern Mexico-nearly 100000 members that make up approximately $1 \%$ of the country's indigenous population (24). The Tarahumara live in small groups clustered and scattered among a mountainous area where the weather varies from cold on the hills to subtropical in the gorges. Health and educational conditions are very poor, mostly due to a history of neglect, but also to geographic isolation and logistical challenges that impede the delivery of services $(25,26)$.

Tarahumara children receive scholarships to attend indigenous boarding schools run by the CDI in the area. In addition to an education, the CDI provides free housing and meals during the school year in shelters located next to the elementary school premises (27). Each school typically hosts 75-150 children; most walk alone to school on Mondays and return home on Fridays. Except for few modern facilities, the vast majority of the schools have precarious infrastructures.

\section{Boarding school selection}

The IS and CS were selected from a list of 38 schools managed by the CDI Guachochi Coordinating Center. Of the total, 34 were old structures, built nearly 30 years ago; and four, were constructed recently. The goal was to select two schools of contrasting infrastructure, but with similar ecological context, based on criteria such as altitude, accessibility, number of children registered, and the willingness of staff to participate.

The IS, located in the Kírare community, at an altitude of $2020 \mathrm{~m}$ and close to a gorge, had been completely rebuilt in 2004. It was hosting approximately 100 children at the time of the study, and was situated in a relatively accessible area adjacent to an unpaved road leading to Batopilas, the municipality's main town. Although its infrastructure was modern, with basic services, such as electricity, water, and sewerage, maintenance of sanitary and kitchen facilities was poor.

In contrast, the CS, located in a highland area of Guachochi, at an altitude of $2300 \mathrm{~m}$, had a very precarious infrastructure. The kitchen, with a surface area of $9 \mathrm{~m}^{2}$, was in very poor condition, as was the $40 \mathrm{~m}^{2}$ eating area where some 120 children had their meals. Solar electricity functioned intermittently; running water and sewerage were not available; and maintenance of the facilities was negligible.

\section{Laboratory diagnosis}

Diagnoses were made by microscopy of two consecutive stool samples. Infected children were given oral nitazoxanide. In those positive for AL/GL at baseline, control samples were taken at 7-10 days after treatment initiation, as others have done (28-30). Those with persistent infections were excluded from the study and retreated (Figure 1).

Fecal specimens of $15 \mathrm{~g}-20 \mathrm{~g}$ were placed in clean, plastic containers and preserved in $10 \%$ formaldehyde solution for up to 3 days before examination. Stool 
FIGURE 1. Flowchart depicting the intervention trial for Ascaris lumbricoides (AL) and Giardia lamblia (GL), Sierra Tarahumara, northern Mexico, 2008

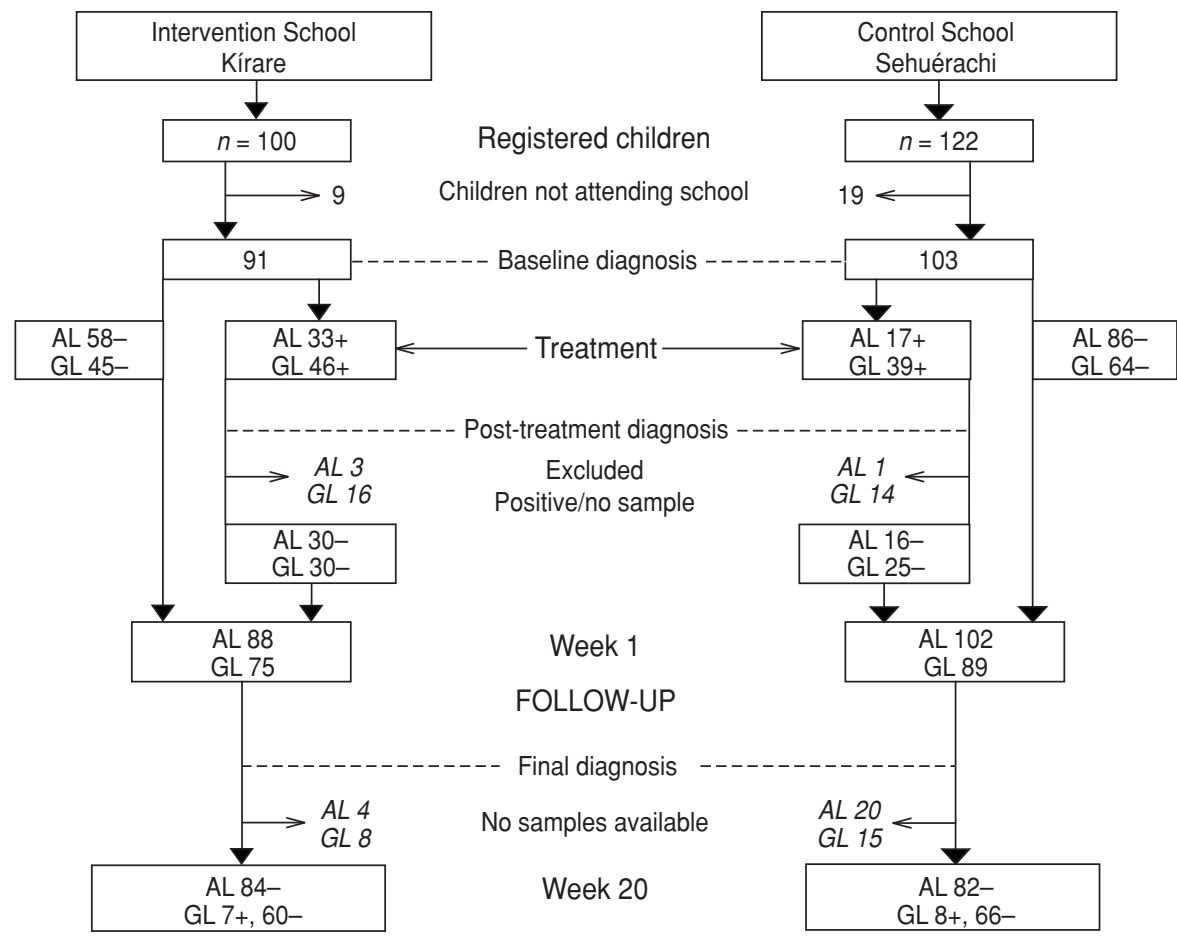

samples were processed using the modified Faust zinc sulfate centrifugal flotation technique to concentrate $\mathrm{AL}$ eggs and GL cysts $(31,32)$. Microscopic observations were made by two experienced laboratory technicians trained and standardized during 2 weeks in the Parasitology Laboratory at the Federico Gómez Children's Hospital (Hospital Infantil de México Federico Gómez, Mexico City). The diagnosis was established when at least 1 of 4 independent observations resulted positive for each parasite.

\section{Antiparasitic treatment}

Children infected with either parasite were given individualized and supervised treatment with a synthetic nitrothiazolylsalicylamide derivative. Oral nitazoxanide was given twice daily for 3 days according to the child's body weight $(\sim 7.5 \mathrm{mg} / \mathrm{kg})$ as follows: $<20 \mathrm{~kg}=200 \mathrm{mg} ; 21 \mathrm{~kg}-30$ $\mathrm{kg}=250 \mathrm{mg} ; 31 \mathrm{~kg}-40 \mathrm{~kg}=350 \mathrm{mg}$; and $>41 \mathrm{~kg}=500 \mathrm{mg}$. Various symptoms, including headache, abdominal pain, nausea, vomiting, and diarrhea were documented as possible side effects.

Cure was defined as the termination of the parasitic infection as a result of treatment; thus therapeutic failure was assumed when the parasitic disease per- sisted after 3-5 days following the termination of the medication. Reinfection referred to any successfully treated child who presented the infection at the end of the follow-up.

\section{Baseline questionnaire and school attendance} interviewed to obtain individual baseline sociodemographic data, including sex, age, languages spoken, school grade, number of persons in the household, size of locality where the dwelling was located, type of floor in dwelling, use of toilet paper for cleansing after defecation, and source of drinking water. The number of days children were absent from school was recorded for the first 3 months of the study. Mean attendance percent was calculated based on the number of days of school attendance divided by the total number of school days in the month.

\section{Intervention}

Table 1, included two major components: (a) physical infrastructure improvements and maintenance; and (b) a broad educational program targeted at children, parents, and boarding school
Children and parents/guardians were personnel. The infrastructure assessment was made by completing a checklist using direct observations, and through key informant interviews to determine needs; the goal was to achieve optimal infrastructure conditions and maintenance throughout the duration of the study. The education component was mainly focused on the use of peer leaders to promote adequate hygiene within and outside of the IS.

The rationale for selecting leaders as "agents of diffusion" to encourage hygienic practices among schoolchildren was grounded in the "innovation diffusion model" and the social network analyses that are detailed elsewhere (33); here, a brief explanation of the strategy is provided.

Identification of leaders. The innovation diffusion theory states that after a person takes notice of an innovation, he/she gains awareness and learns from it, developing a positive or negative attitude that will determine its rejection or acceptance; the premise is that new ideas disseminate through interpersonal communication (34). The social network analyses comprise a pool of methods, some to identify individuals that are "central" within their community, and possibly more influential. The basic model of a diffusion network takes advantage of these "leaders" to initiate and speed up the transmission of new ideas or practices (35).

In this study, all children from the IS were surveyed as a closed network to identify potential leaders that could play a role as agents of diffusion by teaching others peers through their example; the idea was to enhance the impact of the educational intervention. Sociometric data were collected to describe the network structure and to identify leaders (36). Children were asked to mention the names of other children to whom they talked most, and the frequency of such communication (daily, often, sometimes, seldom).

Analyses included the computation of "density" and "centrality" values (37). Density, defined as the proportion of connections between children divided by the total number of possible connections, was used to assess homophilic patterns (i.e., tendency of children to relate with each other based on certain attributes, such as sex or school grade) that would identify the need to select male and female leaders of different grades. 
TABLE 1. Activities carried out at the intervention school to prevent intestinal parasite infections among indigenous children, Sierra Tarahumara, northern Mexico, 2008

\section{INFRASTRUCTURE}

- Installation of liquid soap and paper towel dispensers in the kitchen, eating area, and bathrooms

- Repair of water leaks in the septic tank, lavatories, and toilets; water heater repair and maintenance

- Provision of eating, serving, and food preparing utensils; supply of dishware and drinkware for the kitchen and eating area; distribution of aprons to the indigenous female cooks

- Supply of trash cans with bags, hand towels, vinyl table covers, and various cleaning materials

- Periodic maintenance of all kitchen and sanitary facilities during the study period

- Hiring of a specially-trained indigenous woman to clean up all sanitary facilities twice a day during weekdays for the duration of the study period

\section{EDUCATION}

\section{At school}

- Two $5 \times 2$ m vinyl posters portraying the intervention slogan, "iEn este albergue de la Sierra Tarahumara todos juntos contra la parasitosis!" (At this Sierra Tarahumara boarding school, we're all united against parasites!), were placed at the school main entrance and eating area

- Forty $30 \times 65 \mathrm{~cm}$ informative paper posters with messages and images, aimed at the prevention and control of intestinal parasitic infections, written in Rarámuri and Spanish, were placed in dormitories, eating area, classrooms, and bathrooms to promote understanding and behavioral change

\section{For parents}

- A 2-hour informative talk with parents was conducted in Rarámuri and Spanish at the beginning of the study to explain the purpose of the intervention and to request their cooperation at household level

- Distribution of informative brochures covering various topics, such as food preparation and serving procedures, open defecation measures, water chlorination method, and hand washing procedures

\section{For school personnel}

- Periodic workshops for cooks, covering intestinal parasite control measures (e.g., water disinfection, waste disposal, personal and kitchen hygiene, and food storage/handling/preparation/serving)

- Informative talks with teachers on control measures to prevent intestinal parasite infections so they could help promote positive behavioral change among the schoolchildren

\section{For all children}

- Informative talks in Rarámuri/Spanish in every classroom to explain the purpose of the intervention

- Weekly distribution of an individual "sanitary bag" containing a $50 \mathrm{~g}$ soap bar, a roll of toilet paper, and a 500 $\mathrm{ml}$ bottle with purified water for the use of each child at home during weekends; a $20 \mathrm{ml}$ dropper bottle filled with chlorine-based water disinfectant, and the informative brochure for the child's parents/tutors was also included and distributed every week

- 15 bilingual radio spots lasting 30 seconds each, recorded on cassettes at the indigenous community radio station (XETAR), using traditional music as background and spoken messages aimed at preventing intestinal parasitic infections at school and at the household-level were played daily during mealtimes (07:00, 13:00, 18:00 hours) using a tape recorder

- Three videotape projections, lasting two minutes each, with indigenous children performing activities such as washing hands, eating with utensils or using sanitary facilities, were played three times per week during the "social hour" (19:00-20:00 hours)

\section{For selected leaders}

- The 12 children identified as leaders were made aware of the importance of their role in teaching and promoting hygienic behaviors among their peers in their network of 6-8 kids

- Weekly 2-hour meetings playing didactic games, such as lottery and memory, with cards portraying images related to prevention, transmission, symptoms, and diagnosis of intestinal parasitic infections along with game cards to recognize members of each leader's assigned network, were carried out

- Workshops lasting 2 hours were designed and conducted every 2 weeks with leaders on five themes:

1. What is an intestinal parasite infection?

2. Wash your hands right!

3. Why use utensils for eating?

4. How do you get drinking water?

5. Open fields and nearby areas for defecation

Centrality describes the position of a person within the group's organizational structure; it was assessed using four measures: (a) grade, the number of connections of each child to other children; (b) betweeness, the linking role of a child with others; (c) closeness, the efficiency of the child's role as facilitator of the integration of others; and (d) eigenvector, the popularity role of a child based on his/her connection with other children with high centrality scores.

\section{Data analysis}

Analyses included the comparison of school attendance and sociodemographic characteristics for the followed-up children, and comparisons for AL and GL between children in the IS and CS in terms of baseline prevalence, cure, follow-up, cumulative incidence, and reinfection rates, as defined in Table 2.

Student's t-tests were used to detect mean differences, and Pearson's $\chi^{2}$ and
Fisher tests to identify differences with categorical data. Cohen's kappa coefficients were estimated to assess the interrater agreement for parasite diagnoses between laboratory technicians. The significance level was set at 0.05 . Data was entered and analyzed with IBM $^{\circledR}$ SPSS $^{\circledR}$ version16 (IBM Company, New York, United States of America).

Density and centrality measures were computed with UCINET v.6.143 (Analytic Technologies, Boston, Massachusetts, United States). Children who scored high in the centrality analyses were selected as leaders.

\section{RESULTS}

At the IS, homophilic patterns were seen by sex and grade, which led to the selection of two boys and two girls each for the 1st-2nd grades, 3rd-4th grades, and 5th-6th grades. The 12 selected children scored $>75$ th percentile for all four centrality measures. These peer leaders were responsible for teaching and promoting hygienic practices to the 6-8 students that comprised their network.

Mean overall attendance was $77.9 \%$ at the IS and $82.8 \%$ at the CS $(P>0.05)$, and tended to increase by month at both schools (January, $70.7 \%$ versus $70.8 \%$; February, $79.6 \%$ versus $88.1 \%$; March $82.5 \%$ versus $88.9 \%$ ); attendance was higher among girls, but no clear pattern was seen by age group at either school.

The sociodemographic characteristics of children from the IS and CS were similar except for language spoken, use of toilet paper, and size of the locality where the dwelling was located (Table $3)$; there were significantly more monolingual children at the IS, but more who lived in smaller localities and used toilet paper after defecation at the CS.

Kappa coefficients for the initial prevalence of AL and GL were 0.40 and 0.65 , respectively. At baseline, children at the IS presented a statistically higher proportion of AL infections compared to those at the CS; however, for GL the difference did not reach statistical significance.

Cure rates for AL were similar and very high at both the IS and CS. For GL, cure rates were lower, but also similar at both schools. Follow-up rates for AL were $95.4 \%$ and $80.4 \%$ at the IS and CS, respectively; and for GL, they were $89.3 \%$ and $83.1 \%$, respectively.

After 20 weeks, the GL incidence rate was almost identical at the two schools 
TABLE 2. Operational definitions of the variables used in a study of intestinal parasites among indigenous school children, Sierra Tarahumara, Mexico, 2008

\begin{tabular}{ll}
\hline \multicolumn{1}{c}{ Variables (rates) } & \multicolumn{1}{c}{ Operational definitions $^{\text {a }}$} \\
\hline School attendance & $\frac{\text { No. days of school attendance in the period } \times 100}{\text { Total school days in the period }}$ \\
Baseline prevalence & $\frac{\text { No. children with positive diagnosis at baseline } \times 100}{\text { Total children with stool sample at baseline }}$ \\
Cure & No. children cured from the parasite after treatment $\times 100$ \\
\cline { 2 - 2 } Follow-up & Total children with positive diagnosis at baseline \\
\cline { 2 - 2 } Cumulative incidence & $\frac{\text { Total children at the beginning of follow-up (week } 1)}{\text { No. children with positive diagnosis at week } 20 \times 100}$ \\
\cline { 2 - 2 } Reinfection & $\frac{\text { No. children with positive diagnosis at week } 20 \times 100}{\text { Total children with positive diagnosis at baseline }}$ \\
\hline
\end{tabular}

TABLE 3. Sociodemographic characteristics of children participating in the follow-up portion of the trial of parasitic infections among indigenous school children, by intervention and control schools, Sierra Tarahumara, Mexico, 2008

\begin{tabular}{|c|c|c|c|}
\hline \multirow[b]{2}{*}{ Variable } & \multicolumn{3}{|c|}{ Boarding school } \\
\hline & $\begin{array}{l}\text { Intervention } \\
\quad(n=84)\end{array}$ & $P^{a}$ & $\begin{array}{l}\text { Control } \\
(n=83)\end{array}$ \\
\hline \multicolumn{4}{|l|}{$\operatorname{Sex}(\%)$} \\
\hline Boys & 50 & 1.00 & 49.4 \\
\hline Girls & 50 & & 50.6 \\
\hline Mean $( \pm S D)$ age in years & $8.9( \pm 2.6)$ & 0.12 & $9.5( \pm 2.5)$ \\
\hline \multicolumn{4}{|l|}{ Language spoken $(\%)$} \\
\hline Rarámuri & 35.7 & 0.00 & 6.7 \\
\hline Rarámuri and Spanish & 64.3 & & 93.3 \\
\hline Mean $( \pm S D)$ school grade & $2.8( \pm 1.8)$ & 0.39 & $3.1( \pm 1.7)$ \\
\hline \multicolumn{4}{|l|}{ Size of town of child's residence (\%) } \\
\hline$\leq 15$ households & 45.2 & 0.00 & 72.0 \\
\hline$>15$ households & 54.8 & & 28.0 \\
\hline Mean $( \pm S D)$ number of persons in the household & $6.2( \pm 2.2)$ & 0.87 & $6.3( \pm 2.2)$ \\
\hline \multicolumn{4}{|l|}{ Type of flooring in the household (\%) } \\
\hline Dirt & 72.8 & 0.58 & 77.0 \\
\hline Concrete & 27.2 & & 23.0 \\
\hline \multicolumn{4}{|l|}{ Use of toilet paper after defecation (\%) } \\
\hline Yes & 65.4 & 0.01 & 84.0 \\
\hline No & 34.6 & & 16.0 \\
\hline \multicolumn{4}{|l|}{ Source of drinking water (\%) } \\
\hline Water deposit or deep well & 48.8 & 0.18 & 55.4 \\
\hline River or superficial well & 51.2 & & 44.6 \\
\hline
\end{tabular}

a Student's $t$-tests were used to detect mean differences and Pearson's $\chi^{2}$ tests to identify differences with categorical data.

(IS $10.4 \%$, CS $10.8 \%$ ). No children were infected or reinfected with AL in either school. The reinfection rate for GL was also similar at the schools (IS $17.2 \%$, CS $21 \%)$.

\section{DISCUSSION}

This trial was conducted to determine if a broad intervention that follows WHO guidelines for intestinal parasite control, could be effective among indigenous children in an isolated school setting (18). The goal was to evaluate whether an "ideal" infrastructure, together with a well-designed and implemented educational program, could be effective in preventing intestinal parasitic infections/ reinfections. To assert this, children from a CS had to be deparasited and followedup to establish comparisons.

The study design chosen had an inherent disadvantage that prevented ensuring that the results were due to the inter- vention-it was not possible to guarantee that children were exposed to the intervention, nor to what extent, frequency, and intensity. Regardless, this design was chosen because the purpose was to assess the effectiveness of the best possible intervention that could, if proven successful, be realistically implemented on a large scale.

The principal outcomes defined were the infection and reinfection rates for GL and AL; yet these were very similar at the IS and CS at the end of the trial. This finding suggests that children might be getting infected outside the school premises, and that supervised treatment alone every semester could keep AL/GL infections at relatively low rates. Since children spend weekends and holidays at their homes, where living conditions are often precarious, it is likely that parasite transmission at the community level may be contributing to the prevalent infections observed at baseline and to the incidence and reinfection rates seen at the end of trial.

Interpretation of AL results should be cautious since the presence of diagnostic eggs can take several weeks $(\sim 8-10$ weeks) after first ingestion of embryonated eggs. Therefore, it was not possible to determine the true 20-week infection/reinfection rates for this parasite-some children may have been infected, but could not be diagnosed by microscopy. Extending the follow-up period would have been desirable, but school vacations would have interrupted the intervention, introducing a major source of bias. The results, however, indicate no difference in incidence and reinfection rates for AL between the IS and CS for at least 10-12 weeks.

The results could also be partially explained by other factors, such as laboratory inaccuracies inherent to the sensitivity of the method used, or limited comparability between the schools selected. Although examination of three consecutive, fecal specimens has been recommended for adequate ova and parasite evaluation $(32,38)$, cultural constraints limited the collection to two, which could have led to underdiagnosis of parasites (39). Important difficulties were encountered in obtaining stool samples from the children, especially from older girls who seemed somewhat embarrassed by the procedure; in some cases, indigenous female teachers were needed to help with sample collection. 
TABLE 4. Comparison of baseline prevalence, and cured, follow-up, cumulative incidence, and reinfection rates (\%) for Ascaris lumbricoides and Giardia lamblia, and between children at the intervention and control schools, Sierra Tarahumara, Mexico, 2008

\begin{tabular}{|c|c|c|c|c|c|c|}
\hline \multirow[b]{2}{*}{ Rates } & \multicolumn{3}{|c|}{ Ascaris lumbricoides } & \multicolumn{3}{|c|}{ Giardia lamblia } \\
\hline & $\begin{array}{c}\text { Intervention } \\
\text { school }^{\mathrm{a}}\end{array}$ & $P^{\mathrm{b}}$ & $\begin{array}{l}\text { Control } \\
\text { school }\end{array}$ & $\begin{array}{l}\text { Intervention } \\
\text { school }\end{array}$ & $P^{\mathrm{b}}$ & $\begin{array}{l}\text { Control } \\
\text { school }\end{array}$ \\
\hline Baseline prevalence & 36.2 & 0.003 & 16.5 & 48.3 & 0.10 & 37.8 \\
\hline Cure & 96.8 & 1.0 & 100 & 79.8 & 1.0 & 80.6 \\
\hline Follow-up & 95.4 & 0.007 & 80.4 & 89.3 & 0.36 & 83.1 \\
\hline 20-week incidence & 0 & - & 0 & 10.4 & 1.0 & 10.8 \\
\hline 20-week reinfection & 0 & - & 0 & 17.2 & 1.0 & 21.0 \\
\hline
\end{tabular}

In addition, fresh fecal samples could not be used nor could they be refrigerated due to the logistical challenges. The $10 \%$ formaldehyde solution used to preserve specimens before examination may have diminished ovae and cysts floatability (40).

Although there are other methods of stool examination (e.g., Lutz, Kato-Katz, Willis, Ritchie), some more sensitive than others depending on the parasite, the decision to use the Faust method was primarily based on the possibility of adequately training and standardizing the local lab technicians at one of the largest, certified parasitology laboratories in the country.

Reliability analyses to estimate agreement between technicians for the initial prevalence was relatively high for GL, but lower for $\mathrm{AL}$, adding to limitations for AL data interpretation.

Although the environmental conditions at the two schools seemed relatively similar when planning the study, the importance of the IS location was underestimated. It turned out that many of the student's homes were at lower altitudes, in the gorge area where temperatures are up to $10^{\circ} \mathrm{C}$ higher. These higher temperatures lead to more ecological risks for parasite growth and transmission, potentially reducing the effects of the intervention. In fact, initial prevalence of infected children was higher at the IS for both AL (19.7\%) and GL (10.5\%).

In addition, several baseline sociodemographic and ecological differences between the IS and CS were identified that point to higher risks among IS children, especially at household-level where they spend at least one-third of their time, and where they seem to be getting infected. There were considerably more children in the IS that could only communicate in the indigenous language, more that did not regularly use toilet paper after defecation, and more who lived in larger localities with higher chance of parasite transmission. These factors are believed to have played a role against the impact of the intervention. In retrospect, more attention should have been given to selecting a CS with characteristics and ecological context more similar to that of the IS.

Follow-up rates were somewhat higher at the IS, but no particular reason for differential bias was identified; in fact, the proportion of children not present during the final stool-sampling was slightly higher than the average daily school attendance. Rates ranged from $80 \%-95 \%$, which seem acceptable considering the logistic difficulties involved in the study setting.

Acculturation was not properly addressed, and it is difficult to predict what role this might have played in the risk of parasite infection. In this area, acculturation often relates to imitation of Mestizo $(\sim$ Western) practices, in terms of language (speaking Spanish) and diet (eating Mestizo foods) (25). It could be assumed that acculturated individuals would have better hygienic habits, hence a lesser risk of parasite transmission at home. However, this assumption is controversial because other socioeconomic and environmental factors are interacting as well. Moreover, the potential effect of acculturation at school-level is even trickier; although practices are rather standardized across schools, they may vary depending on the acculturation level of the boarding school staff.

In spite of the concerns expressed by some authors regarding the side effects (29), oral nitazoxanide was chosen for this study because it offers several logistical advantages, including: relatively high cure rates $(\mathrm{AL}>90 \%$; GL > 80\%) $(4,28-30$, 41) that were replicated in this study; the benefit of using a single, broad-spectrum, anti-infective agent instead of having to use antiprotozoal and antihelminthic drugs separately; and the short, 3-day period of administration for effective, supervised treatment. In this study, side effects were minor, mostly abdominal pain reported by few children; only one treatment had to be discontinued.

As to the intervention itself, a creative, educational approach based on culturally tailored methods was tried. The use of peer-leaders as agents of change proved feasible in this study, and could thus be taken into consideration when implementing programs to promote behaviors and practices among Tarahumara schoolchildren as done by others with other population groups $(19,20)$.

Unfortunately, direct comparison with other published trials is not possible because these vary considerably in study design, type of population, follow-up period, antiparasitic treatment, and type of intervention. However, some indirect comparisons can be made. For instance, in a study conducted in rural Argentina, where baseline prevalence for AL and GL was 3.6\% and 7.3\%, respectively, the effect of a 1-year educational intervention alone showed no significant change in the proportion of infected individuals (AL 1.2\%; GL 12\%), even though authors report a slight decrease in overall helminth infections (from $58.2 \%$ to $47.9 \%$; $P=0.01$ ) (42). Regarding reinfection, the results for $\mathrm{AL}$ can be compared with those from a study in tropical India (15) that reported rates of $19.6 \%$ and $35.3 \%$ after 3 months and 6 months, respectively, of successful treatment with a single dose of albendazole $400 \mathrm{mg}$, and even higher rates 
among those $2-14$ years of age $(23.8 \%$ at 3 months).

The results of the present study add to the controversy regarding the roles that education and sanitation play in the prevention and control of intestinal parasitic infections. When attained, positive outcomes are usually seen when prevention and control activities are implemented in combination with antiparasitic treatment (5). However, success in reducing infection rates is by-and-large assessed by surveys that compare the prevalence of intestinal parasites after years of intervention, instead of by controlled studies; but even so, positive results have been obtained even when antiparasitic treatment is given alone, putting in doubt the utility of the educational component $(43,44)$. Nevertheless, the importance of sanitation and education should not be underestimated. While the former seems to play an important role in sustaining the benefits of treatment and protecting the uninfected, the latter appears essential to promoting the conditions for carrying out deparasitation and sanitation campaigns (5).

In the present study, regardless of intervention, there was neither AL incidence nor reinfection, and for GL, both were low. Therefore, the study showed that community-based programs using culturally-appropriate strategies at the household level can help limit environmental factors associated with parasite growth and transmission, especially in high risk areas, such as those close to the gorges.

Even though the lack of differences between schools precluded continuing the intervention at the IS and its introduction at the CS, the results of the trial suggest that intermittent, supervised, antiparasitic treatment alone, every academic semester, could effectively control AL/GL infections in this indigenous setting. This conclusion is particularly relevant given the area's 105 boarding schools and their more than 7000 indigenous students. In addition, extending coverage to the numerous Tarahumara children who are too far from school to attend (> 6 hours) should be considered for reducing AL/GL infection prevalence, intensity of infection, and morbidity in the area (45).

Acknowledgements. The authors wish to thank the children and staff of the Kírare School and Sehuérachi School for their participation in the study, and especially, the peer-leaders for their enthusiastic support. We are very grateful to Marilú Itzel Loya Montiel for her participation during the data collection, and to Eufemia Pérez García and Rogelio Alvarado Rojas for their dedicated laboratory work. Finally, we acknowledge Liomont Laboratories (Laboratorios Liomont, México, D.F., México) for providing the nitazoxanide treatments necessary for the study.

\section{REFERENCES}

1. Roberts LS, Janovy JJ. Foundations of parasitology. 7th ed. New York: McGraw-Hill; 2005.

2. Morales-Espinoza EM, Sánchez-Pérez HJ, García-Gil M del M, Vargas-Morales G, Méndez-Sánchez JD, Pérez-Ramírez M. Intestinal parasites in children, in highly deprived areas in the border region of Chiapas, Mexico. Salud Publica Mex. 2003;45(5):379-88.

3. Quihui L, Valencia ME, Crompton DW, Phillips S, Hagan P, Morales G, et al. Role of the employment status and education of mothers in the prevalence of intestinal parasitic infections in Mexican rural schoolchildren. BMC Public Health. 2006;6:225.

4. Galvan-Ramirez ML, Rivera N, Loeza ME, Avila X, Acero J, Troyo R, et al. Nitazoxanide in the treatment of Ascaris lumbricoides in a rural zone of Colima, Mexico. J Helminthol. 2007;81(3):255-9.

5. Asaolu SO, Ofoezie IE. The role of health education and sanitation in the control of helminth infections. Acta Trop. 2003;86(2-3): 283-94.

6. Nematian J, Nematian E, Gholamrezanezhad A, Asgari AA. Prevalence of intestinal parasitic infections and their relation with socioeconomic factors and hygienic habits in Tehran primary school students. Acta Trop. 2004;92(3):179-86.

7. Gungoren B, Latipov R, Regallet G, Musabaev E. Effect of hygiene promotion on the risk of reinfection rate of intestinal parasites in children in rural Uzbekistan. Trans R Soc Trop Med Hyg. 2007;101(6):564-9.

8. Singh C, Zargar SA, Masoodi I, Shoukat A, Ahmad B. Predictors of intestinal parasitosis in school children of Kashmir: a prospective study. Trop Gastroenterol. 2010;31(2):105-7.

9. Bogitsh BJ, Carter CE, Oeltmann TN. Human parasitology. 3rd ed. Amsterdam: Elsevier Academic Press; 2005.
10. Raso G, Luginbühl A, Adjoua CA, Tian-Bi NT, Silué KD, Matthys B, et al. Multiple parasite infections and their relationship to selfreported morbidity in a community of rural Côte d'Ivoire. Int J Epidemiol. 2004;33(5): 1092-102.

11. Pullan R, Brooker S. The health impact of polyparasitism in humans: are we underestimating the burden of parasitic diseases? Parasitology. 2008;135(7):783-94.

12. Carvalho-Costa FA, Gonçalves $A Q$, Lassance SL, Silva Neto LM, Salmazo CA, Bóia MN. Giardia lamblia and other intestinal parasitic infections and their relationships with nutritional status in children in Brazilian Amazon. Rev Inst Med Trop Sao Paulo. 2007;49(3): 147-53.

13. Nematian J, Gholamrezanezhad A, Nematian E. Giardiasis and other intestinal parasitic infections in relation to anthropometric indicators of malnutrition: a large, populationbased survey of schoolchildren in Tehran. Ann Trop Med Parasitol. 2008;102(3):209-14.

14. Oninla SO, Onayade AA, Owa JA. Impact of intestinal helminthiases on the nutritional status of primary-school children in Osun state, south-western Nigeria. Ann Trop Med Parasitol. 2010;104(7):583-94.

15. Narain K, Medhi GK, Rajguru SK, Mahanta J. Cure and reinfection patterns of geohelminthic infections after treatment in communities inhabiting the tropical rainforest of Assam, India. Southeast Asian J Trop Med Public Health. 2004;35(3):512-7.

16. Saffar MJ, Qaffari J, Khalilian AR, Kosarian M. Rapid reinfection by Giardia lamblia after treatment in a hyperendemic area: the case against treatment. East Mediterr Health J. 2005;11 (1-2):73-8.

17. Hesham Al-Mekhlafi M, Surin J, Atiya AS, Ariffin WA, Mohammed Mahdy AK, Che
Abdullah H. Pattern and predictors of soiltransmitted helminth reinfection among aboriginal schoolchildren in rural Peninsular Malaysia. Acta Trop. 2008;107(2):200-4.

18. Crompton DWT, Montresor A, Nesheim MC, Savioli L. Controlling disease due to helminth infection. Geneva: WHO; 2003.

19. Schuster DV, Valente TW, Skara SN, Wenten MR, Unger JB, Cruz TB, et al. Intermedia processes in the adoption of tobacco control activities among opinion leaders in California. Commun Theory. 2006;16(1):91-117.

20. Kelly JA, Amirkhanian YA, Kabakchieva E, Vassileva S, Vassilev B, McAuliffe TL, et al. Prevention of HIV and sexually transmitted diseases in high risk social networks of young Roma (Gypsy) men in Bulgaria: randomised controlled trial. BMJ. 2006;333(7578):1098.

21. Valente TW. Opinion leader interventions in social networks. BMJ. 2006;333:1082-3.

22. Valente TW, Pumpuang P. Identifying opinion leaders to promote behavior change. Health Educ Behav. 2007;34(6):881-96.

23. Monárrez-Espino J, López-Alarcón M, Greiner T. Randomized placebo-controlled trial of guava juice as a source of ascorbic acid to reduce iron deficiency in Tarahumara indigenous schoolchildren of northern Mexico. J Am Coll Nutr. 2011;30(3):191-200.

24. Instituto Nacional de Estadística Geografía e Informática. Censo general de población y vivienda 2000; tabulados básicos y síntesis de resultados por entidad federativa (Chihuahua). México: INEGI; 2005.

25. Monárrez-Espino J. Health and nutrition in the Tarahumara of northern Mexico. Uppsala; Acta Universitatis Upsaliensis; 2004.

26. Monárrez-Espino J, Martínez H, Martinez V, Greiner T. Nutritional assessment of Tarahumara children at indigenous boarding schools. Eur J Clin Nutr. 2004;58(3):532-40. 
27. Comisión Nacional para el Desarrollo de los Pueblos Indígenas de México. Reglas de operación del 2008 de los programas de la CDI. México: Diario Oficial de la Federación; 2007.

28. Rossignol JF, Ayoub A, Ayers MS. Treatment of diarrhea caused by Giardia intestinalis and Entamoeba histolytica or E. dispar: a randomized, double-blind, placebo-controlled study of nitazoxanide. J Infect Dis. 2001;184(3):381-4.

29. Belkind-Valdovinos U, Belkind-Gerson J, Sánchez-Francia D, Espinoza-Ruiz MM, Lazcano-Ponce E. Evaluación de la nitazoxanida en dosis única y por tres días en parasitosis intestinal. Salud Publica Mex. 2004;46: $333-40$.

30. Escobedo AA, Alvarez G, González ME, Almirall P, Cañete R, Cimerman S, Ruiz A, Pérez $R$. The treatment of giardiasis in children: single-dose tinidazole compared with 3 days of nitazoxanide. Ann Trop Med Parasitol. 2008;102(3):199-207.

31. Faust EC, Sawitz W, Tobie J, Odom V, Peres C, Lincicome DR. Comparative efficiency of various techniques for the diagnosis of protozoa and helminth in feces. J Parasitol. 1939;25: 241-61.

32. National Committee for Clinical Laboratory Standards. Procedures for the recovery and identification of parasites from the intestinal tract (guideline M28-A). Wayne: NCCLS; 1997.
33. Monárrez-Espino J, Caballero-Hoyos R. Stability of centrality measures in social network analyses to identify long-lasting leaders from an indigenous boarding school of northern Mexico. Estud Cult Contemp. 2010;16:155-71.

34. Valente TW. Network models of the difusion of innovations. Creskill: Hampton Press; 1995.

35. Valente TW, Davis RL. Acceleration the diffusion of innovations using opinion leaders. Ann Am Acad Pol Soc Sci. 1999;566(1):55-67.

36. Valente TW. Network Analysis in Public Health. Baltimore: Johns Hopkins University; 1997.

37. Hanneman RA, Riddle M. Introduction to social network methods. Riverside: University of California Riverside; 2005.

38. Van Gool T, Weijts T, Lommersee E, Mank TG. Triple Faeces Test: An effective tool for detection of intestinal parasites in routine clinical practice. Eur J Clin Microbiol Infect Dis. 2003;22(5):284-90.

39. Knopp S, Mgeni AF, Khamis IS, Steinmann P, Stothard JR, Rollinson D, et al. Diagnosis of soil-transmitted helminths in the era of preventive chemotherapy: effect of multiple stool sampling and use of different diagnostic techniques. PLoS Negl Trop Dis. 2008;2(11):e331.

40. Moitinho M, Bertoli M, Guedes TA, Ferreira $\mathrm{CS}$. Influence of refrigeration and formalin on the floatability of Giardia duodenalis cysts. Mem Inst Oswaldo Cruz. 1999;94(4):571-4.
41. Diaz E, Mondragon J, Ramirez E, Bernal R Epidemiology and control of intestinal parasites with nitazoxanide in children in Mexico. Am J Trop Med Hyg. 2003;68(4):384-5.

42. Pezzani BC, Minvielle MC, Ciarmela ML, Apezteguía MC, Basualdo JA. Participación comunitaria en el control de las parasitosis intestinales en una localidad rural de Argentina. Rev Panam Salud Publica. 2009;26(6):471-7.

43. Ulukanligil $\mathrm{M}$. The results of a control program carried out on school children for intestinal parasites in Sanliurfa province, Turkey between the years of 2001 and 2005. Turkiye Parazitol Derg. 2006;30(1):39-45.

44. Bóia MN, Carvalho-Costa FA, Sodré FC, EyerSilva WA, Lamas CC, Lyra MR et al. Mass treatment for intestinal helminthiasis control in an Amazonian endemic area in Brazil. Rev Inst Med Trop Sao Paulo. 2006;48(4):189-95.

45. Olsen A. Experience with school-based interventions against soil-transmitted helminths and extension of coverage to non-enrolled children. Acta Trop. 2003;86(2-3):255-66.

Manuscript received on 22 October 2010. Revised version accepted for publication on 13 May 2011.
RESUMEN

\section{Intervención para prevenir las reinfecciones parasitarias intestinales en niños indígenas tarahumara en edad escolar en el norte de México}

\author{
Palabras clave
}

Objetivo. Evaluar la eficacia de una intervención amplia de 20 semanas de duración para prevenir la reinfección por Ascaris lumbricoides y Giardia lamblia en niños indígenas en edad escolar del norte de México.

Métodos. Estudio prospectivo, de comparación y ecológico. Se seleccionaron dos internados geográficamente aislados, cada uno de los cuales alberga entre 100 y 120 niños de 4 a 15 años de edad, según su infraestructura física: una escuela moderna en la que se llevó a cabo la intervención y otra, precaria, que se empleó como control. Tras el diagnóstico inicial, los niños con resultados positivos en los análisis de las muestras de heces recibieron tratamiento supervisado con nitazoxanida oral. El diagnóstico se hizo con al menos un resultado microscópico positivo en dos muestras sucesivas con la técnica de Faust, según lo informado por las observaciones independientes efectuadas por dos técnicos de laboratorio capacitados. Se tomaron muestras postratamiento y solo se hizo el seguimiento de los niños con resultados negativos. La intervención incluyó mejoras y mantenimiento de la infraestructura y un programa educativo de prevención para los niños, los padres y el personal de la escuela; en la escuela de control no se llevó a cabo ninguna actividad.

Resultados. La prevalencia inicial de la infección por $A$. lumbricoides fue de 37,5\% en la escuela de la intervención frente a $16,6 \%$ en la escuela de control $(P<0,01)$; la de G. lamblia, de $51,7 \%$ frente a $37,8 \%$, respectivamente. En la escuela de la intervención $35,7 \%$ no hablaba español, en comparación con 6,7\% en la escuela de control $(P<0,01)$. Las tasas de curación fueron similares en ambas escuelas para A. lumbricoides (aproximadamente $98 \%$ ) y para G. lamblia (aproximadamente $80 \%$ ). La prevalencia final y las tasas de reinfección para G. lamblia fueron de $10,4 \%$ frente a 10,8\% en la escuela de la intervención y de $17,2 \%$ frente a $21 \%$ en la escuela de control. No hubo nuevas infecciones o reinfecciones con $A$. lumbricoides en ninguna de las escuelas. Las tasas de seguimiento fueron de $80 \%$ a $83 \%$ en la escuela de control y de $90 \%$ a $95 \%$ en la escuela de la intervención.

Conclusiones. Las tasas de infección o reinfección fueron similares en las dos escuelas después de 20 semanas. El tratamiento supervisado cada semestre como única medida controló eficazmente las infecciones con A. lumbricoides o G. lamblia en este entorno indígena.

Enfermedades parasitarias; ascariasis; giardiasis; población indígena; salud indígena; estudios de intervención; saneamiento de escuelas; México. 